\title{
Summer distribution of beluga whales (Delphinapterus leucas) in the Sea of Okhotsk
}

\author{
Boris A. Solovyev*, Olga V. Shpak, Dmitri M. Glazov, Vyacheslav V. Rozhnov, \\ Daria M. Kuznetsova
}

\begin{abstract}
The summer distribution of beluga whales (Delphinapterus leucas) in the Sea of Okhotsk is typical for boreal and subarctic seas that are seasonally ice covered and support numerous anadromous fish species. During summer in the Sea of Okhotsk, beluga whales aggregate where rivers flow into estuaries, gulfs, and bays. Beluga whales are currently found in Sakhalinskiy Bay (in an estuary of the Amur River), the Shantar region, in portions of Shelikhov Bay, and along the northwestern coast of the Kamchatka Peninsula. Changes in beluga whale distribution have occurred when compared to results of earlier studies. In particular, summer aggregations have increased in the Shantar region and along the northwestern coast of the Kamchatka Peninsula.
\end{abstract}

KEY WORDS: beluga whales, geographic distribution, Sea of Okhotsk

Boris A. Solovyev [solovyev.boris@gmail.com] Faculty of Geography, M.V. Lomonosov Moscow State University, 112, Leninskie Gory, Moscow, 119234, Russia, A.N. Severtsov Institute of Ecology and Evolution, RAS, 33, Leninsky prospekt, Moscow 119071, Russia; Olga V. Shpak [ovshpak@gmail.com] A.N. Severtsov Institute of Ecology and Evolution, RAS, 33, Leninsky prospekt, Moscow 119071, Russia Marine Mammal Council 36, Nakhimovskiy prospekt, Moscow, 117997, Russia; Dmitri M. Glazov [dglazov@yandex.ru] A.N. Severtsov Institute of Ecology and Evolution, RAS, 33, Leninsky prospekt, Moscow 119071, Russia Marine Mammal Council 36, Nakhimovskiy prospekt, Moscow, 117997, Russia; VyacheslavV. Rozhnov [rozhnov.v@gmail.com] A.N. Severtsov Institute of Ecology and Evolution, RAS, 33, Leninsky prospekt, Moscow 119071; Daria M. Kuznetsova [belyi.kit@gmail.com] A.N. Severtsov Institute of Ecology and Evolution, RAS, 33, Leninsky prospekt, Moscow 119071.

\section{Летнее распределение белухи (Delphinapterus leucas) в Охотском море}

\section{Б. А. Соловьёв, О.В. Шпак, Д.М. Глазов, В.В. Рожнов, Д.М. Кузнецова}

РЕЗЮМЕ: Летнее распределение белухи Охотского моря типично для бореальных и субарктических морей с сезонным ледовым покровом и значительными запасами анадромных видов рыб. В летний сезон белуха концентрируется в вершинах заливов, эстуариях в некоторых районах, таких как Сахалинский залив (Амурский лиман), Шантарский район, отдельные районы залива Шелихова, северо-западное побережье Камчатки. Существуют некоторые различия между современным распределением белухи в Охотском море и распределением, описанным по результатам предыдущих исследований. Так, роль Шатарского района и северо-западного побережья Камчатки, как мест летних концентраций белухи, согласно представленному исследованию увеличилась.

КЛЮЧЕВЫЕ СЛОВА: белуха, географическое распределение, Охотское море.

\section{Introduction}

The Sea of Okhotsk is the southernmost portion of the range occupied by beluga whales (Delphinapterus leucas Pallas, 1776) in the western North Pacific (Shpak et al., 2010). Individual beluga whales have been observed in the Sea of Japan (Sato \& Ichimura, 2011; Melnikov \& Seredkin, 2014); however, such cases are rare and should be considered extralimital. Beluga whales remain year-round in the Sea of Okhotsk, in relatively deep, ice-covered, offshore waters during winter and aggregate in coastal regions and river estuaries in the summer (Arseniev, 1939; Kleinenberg et al., 1964; Fedoseev, 1986; Shpak et al., 2010; Shulezhko et al., 2013).

In the $20^{\text {th }}$ century, this species was hunted intensively by commercial whalers. The first scientific data on distribution, abundance, migration and seasonal movements in the Sea of Okhotsk were collected during this period of commercial whaling (1930-60s). However, no comprehensive data on distribution were obtained because research primarily focused on areas accessible to commercial whalers. Beginning in the early 1970s, scientific studies focused on beluga whale abundance and distribution in the Sea of Okhotsk were conducted during ship-based and aerial surveys. These 


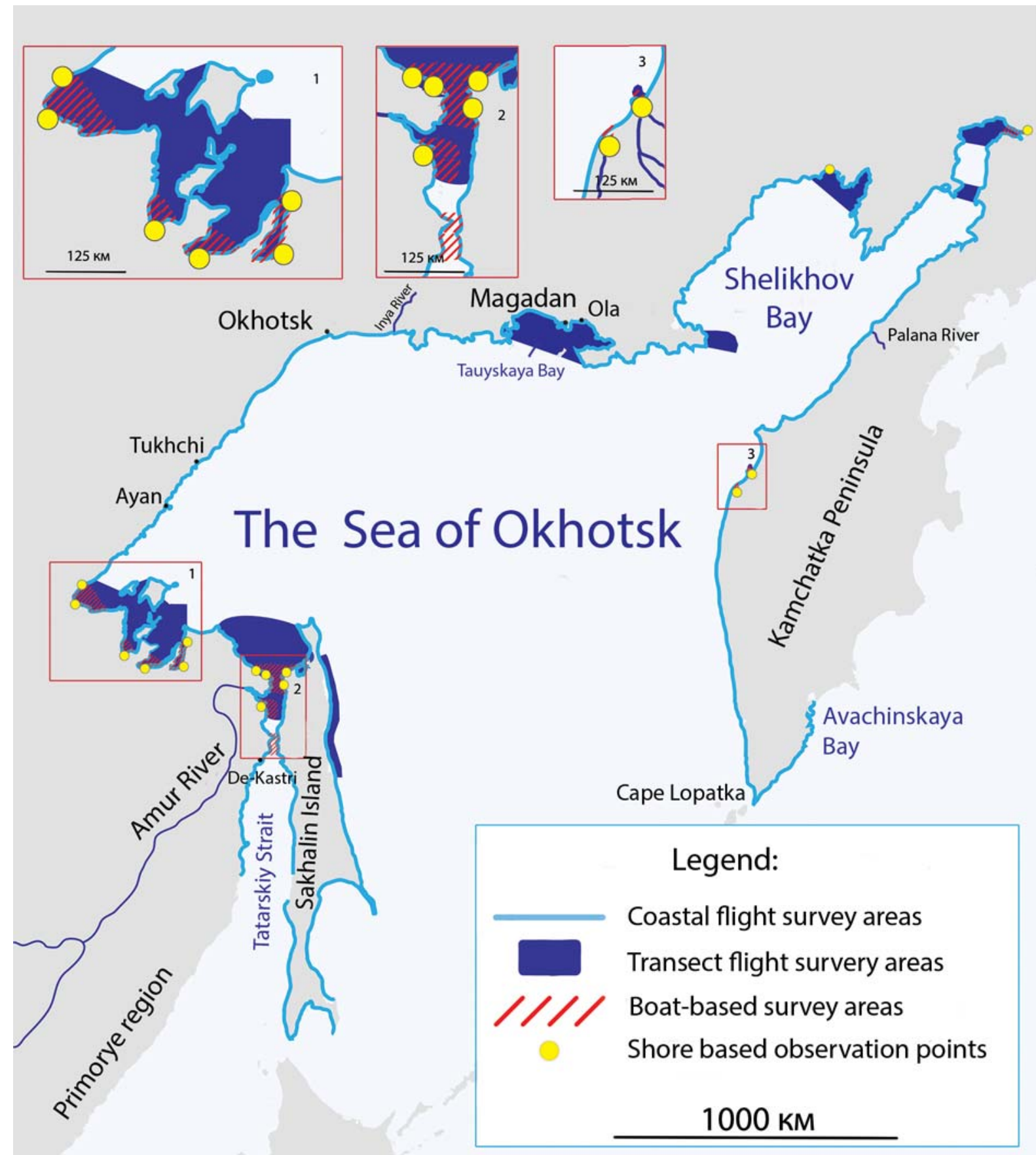

Fig. 1. The areas of the shore/ship based and aerial surveys conducted in 2007-2014 to study the distribution of beluga whales.

extensive studies were interrupted in the early 1990s, and resumed only in recent years.

Based on these earlier studies, during the first half of the $20^{\text {th }}$ century summer aggregations of beluga whales regularly occurred in the northern part of the Tatarskiy Strait, the estuary of the Amur River, Sakhalinskiy Bay, Nikolaya Bay, Ulbanskiy Bay, Tugurskiy Bay and Udskaya Bay, the estuary of the Ayan River, and Tauyskaya Bay, Gizhiginskaya Bay and Penzhinskaya Bay (Arseniev, 1939; Kleinenberg et al., 1964). In the second half of the $20^{\text {th }}$ century, researchers enumerated the main aggregations of beluga whales. They determined that in the western Sea of Okhotsk, the Amur River and its estuary provided habitat for the largest population of beluga whales in this region (Berzin et al., 1988; Berzin, Vladimirov, 1989). In the eastern Sea of Okhotsk, the largest population occupied Shelikhov Bay, including Gizhiginskaya and Penzhinskaya Bays (Berzin at al., 1988; Berzin, Vladimirov, 1989; Vladimirov, 1994). Although a significant amount of commercial whaling 
Table 1. The time periods and areas of ship and shore based observations.

\begin{tabular}{|c|c|c|}
\hline Area of observations & Year & Time period of observations \\
\hline \multicolumn{3}{|c|}{ Aerial observations } \\
\hline \multirow{2}{*}{ Sakhalin-Amur region, Shantar region, North-Western region } & 2009 & $05.08-08.08$ \\
\hline & 2009 & $11.09-13.09$ \\
\hline Western Kamchatka and Shelikhov region & 2009 & $16.08-02.09$ \\
\hline \multirow{2}{*}{ Sakhalin-Amur region, Shantar region, North-Western region } & 2010 & $07.08-08.08$ \\
\hline & 2010 & $23.08-24.08$ \\
\hline Western Kamchatka and Shelikhov region & 2010 & $10.08-19.08$ \\
\hline \multicolumn{3}{|c|}{ Ship and shore based observations } \\
\hline Gizhiginskaya Bay & 2004 & $27.05-08.06$ \\
\hline Penzhinskaya Bay & 2010 & $28.06-08.07$ \\
\hline \multirow{3}{*}{ Estuaries of the Khairyuzova and Belogolovaya Rivers } & 2010 & $30.07-31.08$ \\
\hline & 2011 & $13-14.08,14-18.09$ \\
\hline & 2012 & $13.07-28.08$ \\
\hline Estuary of the Moroshechnaya River & 2011 & $17.08-13.09$ \\
\hline \multirow{7}{*}{ Sakhalinskiy Bay and Amur Estuary } & 2007 & $19.08-24.08$ \\
\hline & 2008 & $06.07-16.07$ \\
\hline & 2009 & $24.07-07.08$ \\
\hline & 2010 & $09.06-4.09$ \\
\hline & 2011 & $07.07-27.08$ \\
\hline & 2013 & $20.07-21.09$ \\
\hline & 2014 & $27.07-28.08$ \\
\hline \multirow{3}{*}{ Nikolaya Bay } & 2009 & $27.06-20.07$ \\
\hline & 2010 & $17.07-02.08$ \\
\hline & 2012 & $17.08-26.08$ \\
\hline \multirow{4}{*}{ Ulbanskiy Bay } & 2010 & $07.07-09.08$ \\
\hline & 2011 & $08.07-18.08$ \\
\hline & 2012 & $15.07-03.09$ \\
\hline & 2013 & $12.08-27.08$ \\
\hline \multirow{2}{*}{ Tugurskiy Bay } & 2010 & $21.06-12.09$ \\
\hline & 2013 & $02.08-11.08$ \\
\hline \multirow{3}{*}{ Udskaya Bay } & 2010 & $23.08-12.09$ \\
\hline & 2012 & $29.06-14.07,04-13.09$ \\
\hline & 2013 & $09.07-01.08$ \\
\hline
\end{tabular}

occurred in Tauyskaya Bay, beluga whales were not observed there in the second half of the $20^{\text {th }}$ century (Melnikov, 2001).

Our study updates information on the summer distribution of beluga whales in the Sea of Okhotsk and identifies changes in distribution that have taken place within this region.

\section{Material and Methods}

This paper presents the results of studies conducted by the authors in the Sea of Okhotsk in 2007-2014 (Fig. 1). The overall pattern of present-day beluga whale distribution was based on data collected during summer aerial surveys in 2009-2010. Information about the presence of belugas in specific bays and estuaries was obtained from shore-based observations, observations from ships and boats, and interviews with local residents and fishermen. Satellite-linked transmitters attached to individual beluga whales provided location data that were used to learn about their movement and migration patterns.
Aerial surveys. Bays of the Sea of Okhotsk and its coastline were surveyed in 2009 and 2010, excluding the Kuril Islands chain. Surveys were conducted from August 3 to September 13 in 2009 and from August 4 to August 24 in 2010, covering the Sakhalin-Amur and Shantar regions two times each year. Bays were surveyed using standard line transect methodology while other coastal areas were surveyed during a single coastal transect [see Glazov et al. (2012) for methodology and beluga whale abundance estimates].

Shore based and ship-based surveys. Shore based observations and studies of behaviour and local movements of belugas were conducted during the summer in the western Sea of Okhotsk in the Amur Estuary, Sakhalinskiy, Nikolaya, Ulbanskiy, Tugurskiy and Udskaya bays. In the northeastern region, shore and ship based surveys were conducted in the estuaries of the Moroshechnaya, Khairyuzova and Belogolovaya rivers, as well as in Penzhinskaya Bay. Research efforts varied among regions and years (Table 1 ).

Interviews. Over the seven year period, local residents, fishermen, and fishing inspectors were inter- 
viewed about marine mammals seen near settlements and shore-based industrial facilities. The respondents were asked the following questions: 'Did you observe beluga whales in the vicinity of your place of residence/ work, and if so, when do they arrive in the area and leave it?' Answers to the latter question also included more general responses such as 'after ice break-up', 'they came with fish' etc. In addition to beluga observations, the respondents were asked to provide information about when fish approach the coast and in what quantity. Over 150 persons were interviewed in 28 locations, including more than 100 persons in 19 locations in the western region.

Other sources of information. Earlier published data co-authored by the authors of this paper - results of genetic analysis (Meshchersky et al., 2012, 2013; Yazykova et al., 2012), satellite tracking (Shpak et al., 2010, 2012; Shpak \& Glazov, 2013), and photo-identification - were included to provide additional insights about beluga whale distribution. Nikon D90 and D300 cameras with Nikkor $28-300 \mathrm{~mm} \mathrm{f/3.5-5.6} \mathrm{VR} \mathrm{and}$ Nikkor 70-200 mm f/2.8G AF-S VR IF-ED lens were used for photo-identification. Photographs were analyzed with IrfanView 4.37 software.

Distribution mapping and analyses. Ship/shore based and aerial survey data were transformed into a format compatible with GIS processing software. To visualize beluga whale distribution patterns, Adobe Illustrator CS 3 and Adobe Photoshop CS 3 PC software were used with the Natural Earth vector map available in the public domain as a map base.

For convenience, we divided the Sea of Okhotsk into the following regions (Fig. 1):

- Shelikhov region - Shelikhov Bay including Penzhinskaya and Gizhiginskaya Bays;

- Western Kamchatka region - the coastal area between Lopatka Cape and the Palana River in the north;

- Sakhalin-Amur region - Sakhalinskiy Bay including Baikal Bay, Amur Estuary and the northern part of the Tatarskiy Strait;

- Shantar region - the so-called 'Shantar Sea' including Udskaya Bay, Tugurskiy Bay, Nikolaya Bay and Ulbanskiy Bay;

- Northwestern region - the coastal area between Udskaya Bay and Shelikhov Bay.

ANOVA was carried out using results of repeated counts $(n=36)$ as depending variable and geographical place as grouping variable. The analysis was conducted in R 2.14 software (2008).

\section{Results}

\section{Shelikhov region}

Gizhiginskaya Bay - According to evidence of respondents residing near Nayakhanskaya Bay, beluga whales approach the coast during the herring (Clupea pallasii) spawning season in May after sea ice retreats. The main aggregation of several scores of belugas is observed in the northern part of the bay with individual whales or small groups of 2-3 belugas seen along the eastern coast.

In late May or the first half of June, the smelt (Hypomesus sp.) run begins lasting 10-14 days (Chereshnev et al., 2001). During this time, beluga whales gather in Avekova Bay. Belugas are also present in Avekova Bay in July and August during pink (Oncorhynchus gorbuscha) and chum salmon (O. keta) runs.

The maximum number of belugas in Gizhiginskaya Bay observed during the aerial surveys in 2009 and 2010 reached 250-300 whales (Fig. 2). Similar to the bays of the Shantar region, belugas stay in the estuaries of the Gizhiga and Avekova rivers in August. However, during one aerial survey flight in mid-August, a dense aggregation of over 120 beluga whales was discovered opposite a rocky shore on the east coast of the Gizhiginskaya Bay. Further north another group of over 20 whales was observed, also near the shore on the east coast of the Gizhiginskaya Bay.

Penzhinskaya Bay - According to evidence of respondents in Manily, an inland settlement on the Penzhina River which flows into Penzhinskaya Bay, beluga whales come here twice a year - in late May or early June during the smelt run and in the second third of July and August during the salmon run. Beluga whales often go from the estuary up the Penzhina River, reaching Manily settlement and sometimes continuing upriver. Extreme high tides are observed in Penzhinskaya Bay, especially at the river estuaries where tidal range is up to $12 \mathrm{~m}$. Respondents noted beluga whales have to adapt to quick changes in water levels and rapid tidal currents.

As beluga whales move along the coast, they drive fish to nearshore waters within numerous capes. Water levels near these capes remain deep enough to allow whales to stay during low tide. During the rising tide, whales move along river channels, also searching for prey near capes. According to evidence of respondents, beluga whales are occasionally trapped on the mud flats at low tide and their skin becomes dry, but they remain calm and wait for the next high tide then swim away.

During summer, local residents in Manily usually see groups consisting of 15-20 belugas. In general, beluga whales do not gather in large, dense aggregations in Penzhinskaya Bay but spread out relatively uniformly in small groups in the area near the estuary of the Penzhina River.

During boat and shore based surveys in late June and early July 2010, individual belugas and small groups up to 3 whales were observed in the Penzhina River estuary (Fig. 2). One day a group of ca. 10 belugas of different ages was observed. The belugas appeared in the river near Manily settlement at the beginning of high tide and left at the beginning of low tide. Behaviours observed included resting and feeding. Aerial surveys conducted in the second half of August found up to 250 beluga whales in the estuaries of the Penzhina and Talovka Rivers. Belugas were also observed along 


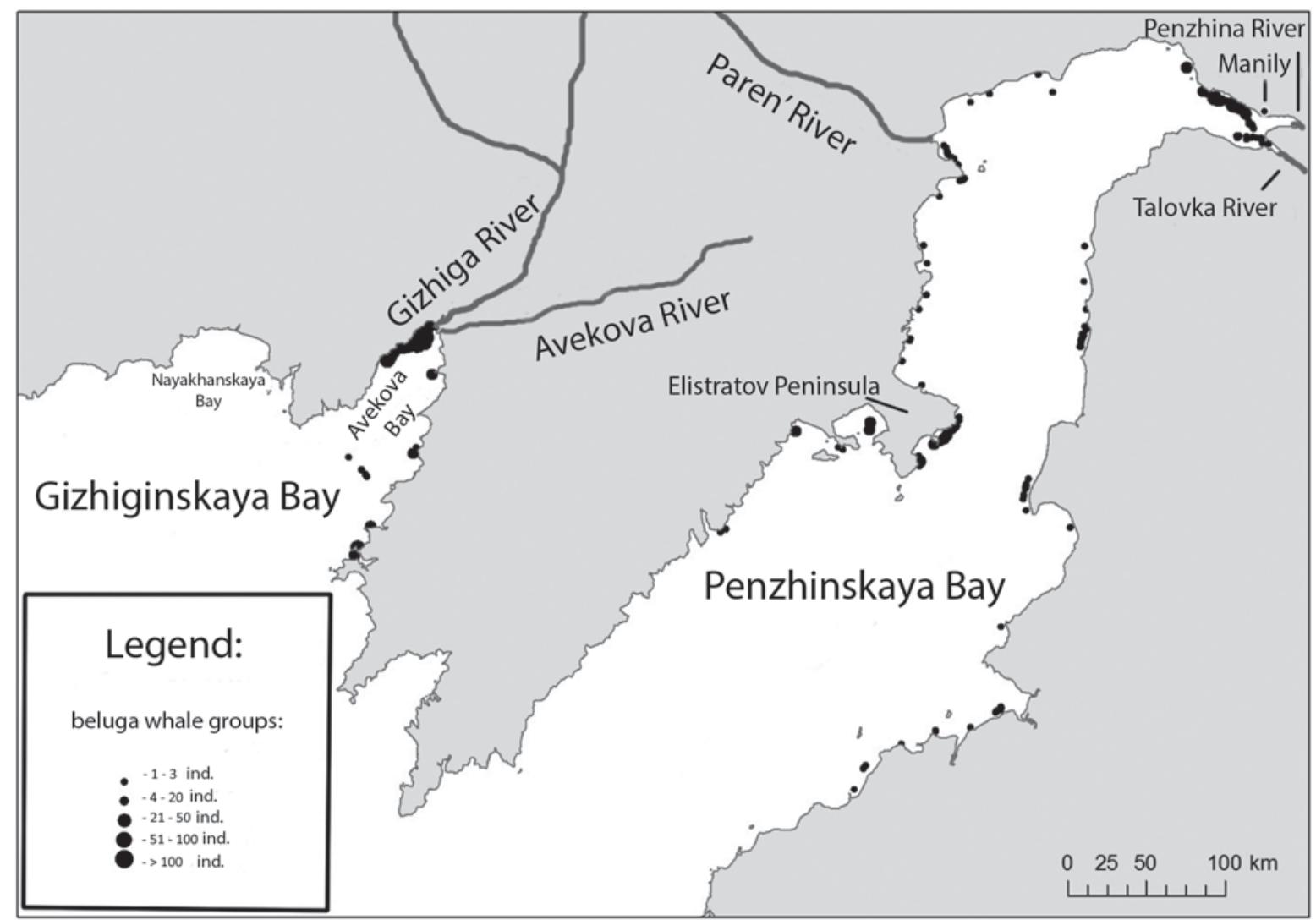

Fig. 2. Summer sightings of beluga whales in Shelikhov Bay during the aerial surveys in 2009-2010.

the entire coast of the bay. Up to 40 beluga whales were seen along the east coast of the bay, with several juveniles among them, and over 120 belugas along the west coast. The densest aggregation of belugas (about 60 whales) was observed in the central area of the bay near the Elistratov Peninsula. According to our observations and interviews of local residents, a small but permanent aggregation exists in the estuary of the Paren' River in the northwestern part of the bay. Up to 20 belugas were seen here during the aerial surveys.

The pattern of beluga whales distribution in Penzhinskaya Bay is somewhat different from whales in the Shantar region and Gizhiginskaya Bay — belugas are sighted not only in the river estuaries but also along the entire coastline of the bay.

\section{Western Kamchatka region}

According to evidence of interview respondents, beluga whales come to the west coast of Kamchatka Peninsula twice - the first time in the second half of May or beginning of June when smelt arrives and the second time in mid-summer remaining until the beginning or even the end of October; feeding on different salmon species spawning runs.

Aerial surveys found the largest aggregation of beluga whales in the estuary of the Khairyuzova and Bel- ogolovaya rivers (Fig. 3: inset), where we spotted up to 250-300 belugas. Smaller aggregations were observed in the estuaries of the Moroshechnaya River (up to 90 belugas), Tigil River (up to 115 belugas) and Voyampolka River (up to 140 belugas). In the estuaries of all other rivers northeast along the coast from the Khairyuzova River to the Palana River, beluga whales were seen only in relatively small numbers. We infrequently observed individual belugas and belugas in small groups along the coast between river estuaries. Often they were travelling along the shore near the surf line.

Boat and shore based observations occurred in JulySeptember 2010-2012 in the estuaries of the Khairyuzova, Belogolovaya and Moroshechnaya Rivers (Table 1). Numbers of belugas in the Moroshechnaya River estuary fluctuated notably - from 11 to 111 belugas during the observation period. In the Khairyuzova and Belogolovaya estuary and the adjacent coastal area, the numbers of beluga whales remained more stable (250300 whales).

According to evidence of fishermen and local residents, beluga whales are not seen in large numbers or with any regularity south of the Moroshechnaya River. During our observation flights the $1^{\text {st }}$ week of September 2009, belugas were observed near almost every river mouth within this area (Fig. 3), but in August 2010 , only few were detected along this part of the 


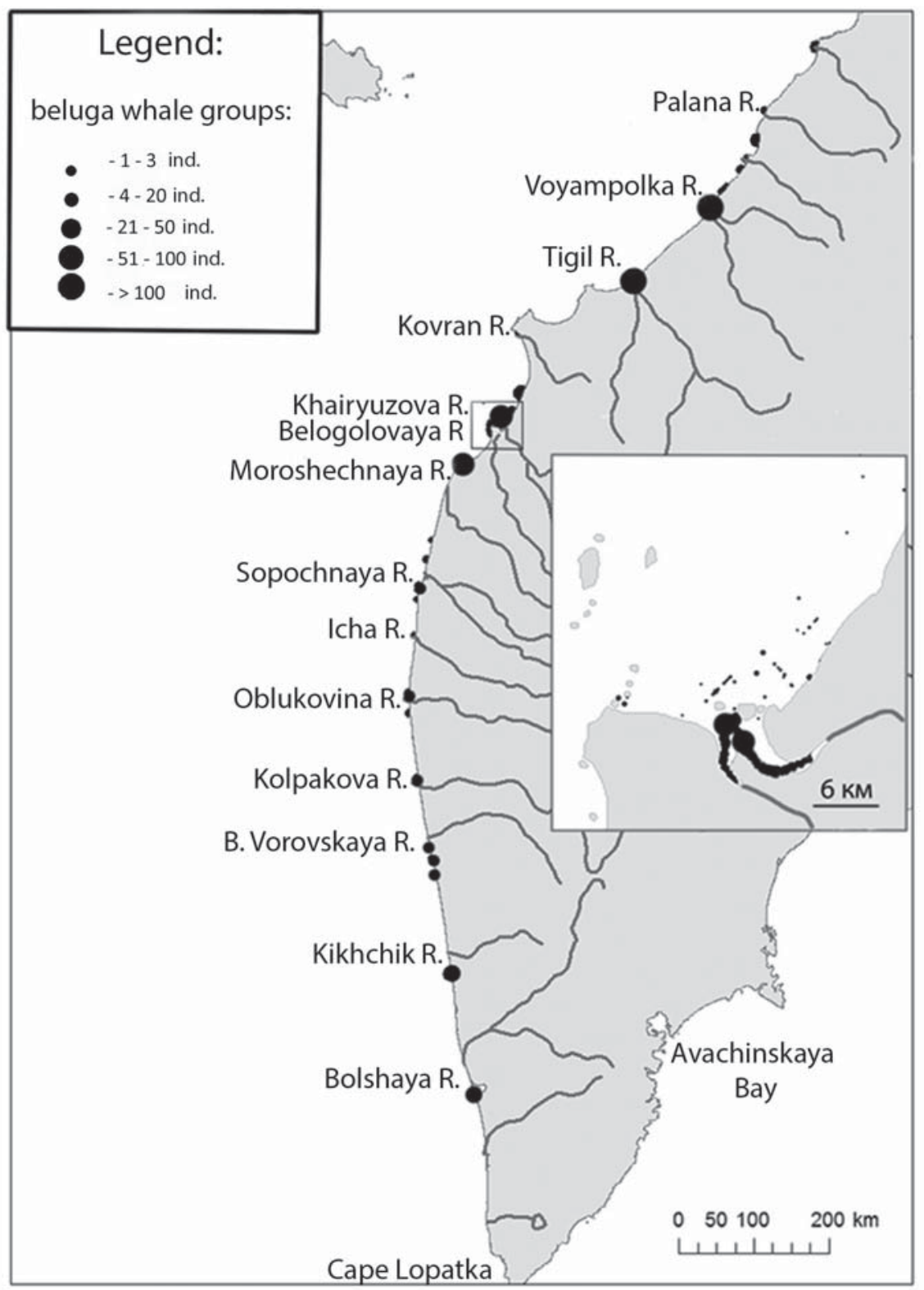

Fig. 3. Summer sightings of beluga whales near the coast of the Kamchatka Peninsula during ship-based and aerial surveys in 2009-2012.

Kamchatka coast. Sightings in 2009 occurred near the Sopochnaya River (29 belugas), Icha River (1 beluga), Oblukovina River (6 belugas), Kolpakova River ( 8 belugas), Bolshaya Vorovskaya River (17 belugas), Kikhchik River (35 belugas), and Bolshaya River (ca. 50 belugas). Almost three times as many beluga whales were observed along the peninsula north of Moroshechnaya River when compared to the peninsula south of the river (ANOVA, $\mathrm{p}=0.05$ ).

Beluga whales were not seen along the eastern coast of Kamchatka from Avachinskaya Bay to Lopatka Cape during the aerial surveys in 2009. Also, no sightings were reported in these areas by other researchers or respondents.
Photo-identification studies confirmed movement of some individuals between estuaries, supporting the idea that belugas aggregating in the river estuaries of western Kamchatka may move along the coast during the summer season, presumably, depending on feeding conditions.

Similar data were collected using satellite tracking in the Khairyuzova River estuary (3 transmitters deployed in 2011) and the Moroshechnaya River estuary (1 transmitter deployed in 2011) (Tarasyan et al., 2013; Shulezhko et al., 2013). When we compared tracking data to fish run strength (data based on interviews), whales appeared to travel to another estuary only if there was a shortage of fish. In late August 2010, beluga 


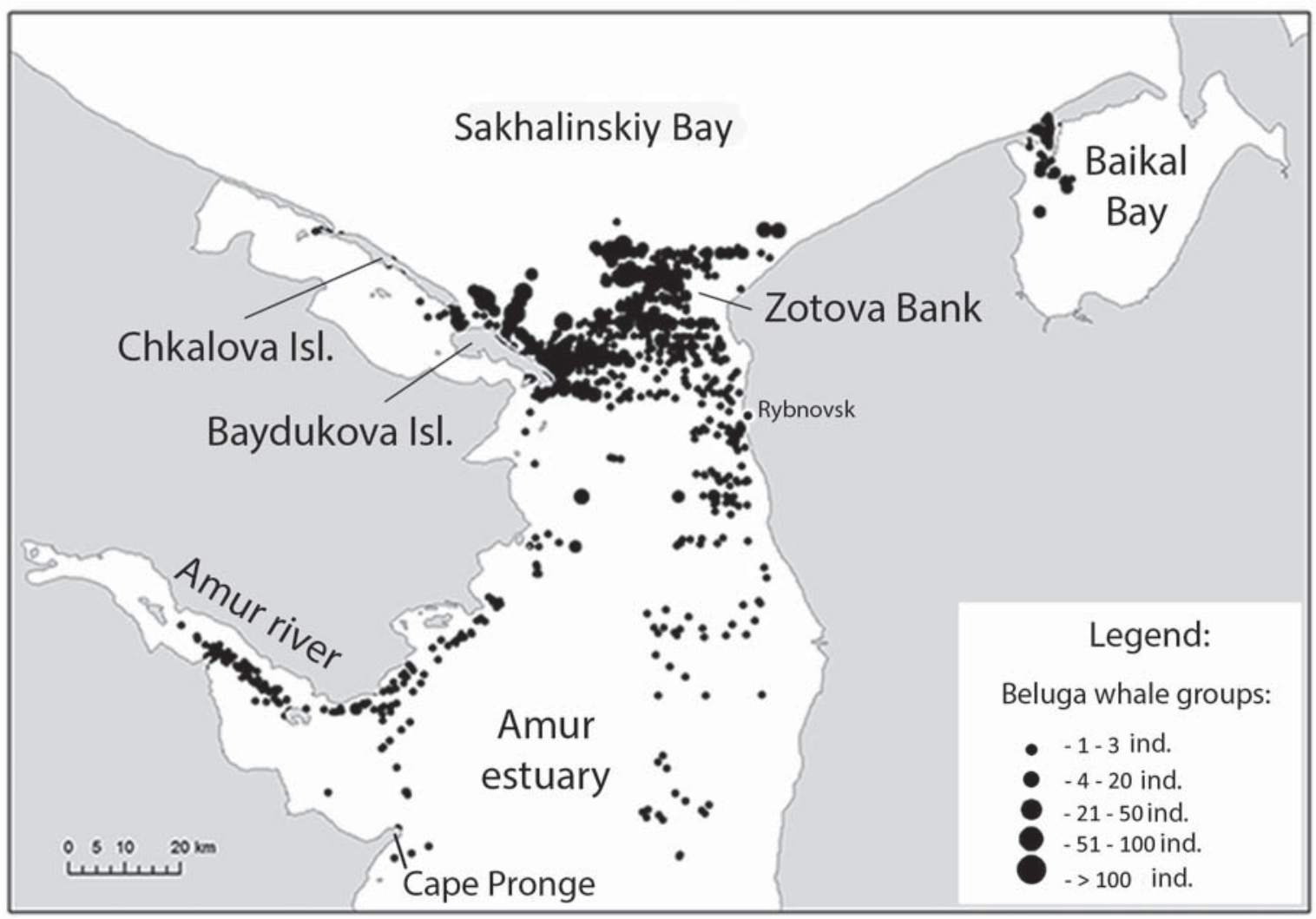

Fig. 4. Summer sightings of beluga whales in the Sakhalinskiy Bay and the Estuary of the Amur River according to the results of the ship-based and aerial surveys in 2007-2013.

whales temporarily left en masse the estuary of the Khairyuzova and Belogolovaya rivers after the pink salmon run ended, traveling north to the Kovran River where the pink salmon run was beginning. Also, according to evidence of residents of Ust-Khairyuzovo settlement, it seemed that beluga whales left their favourite feeding places in the estuaries of the Khairyuzova and Belogolovaya Rivers in September 2011, when there were few fish in the river, and came back later that year. In October - early November 2010 and 2011, the satellite tracked belugas began slowly moving north to the estuary of the Lesnaya River (in 2010) or the southern part of Penzhinskaya Bay (in 2011).

\section{Sakhalin-Amur region}

According to evidence of numerous interview respondents, beluga whales arrive in Sakhalinskiy Bay and the Amur Estuary right after the area becomes clear of ice. Typically this happens in the middle or the second half of May or sometimes later - in the beginning of June (depending on ice conditions) 'together with various species of fish' (usually herring or smelt). The whales arrive from the north - northern part of Sakhalin Island (the area near Rybnovsk) and from the south - the direction of Tatarskiy Strait. If there is no fish, the belugas leave the region. Fishermen reported that the belugas remain in the area during several days, "blocking" the channel at the southernmost point of Zotova Bank, then leave following the fish into the Amur Estuary. After the end of the fish run, the whales move north before returning to the bay with the next fish run. In May, groups composed of 'several dozen' of beluga whales feed on herring as far south as DeKastri settlement.

According to our observations, in summer the main aggregation of belugas is located on the boundary between Sakhalinskiy Bay and the Amur Estuary - between Baydukova Island and Zotova Bank (Fig. 4). Here the bay is at its most narrow, forcing returning salmon run into a confined space which belugas take advantage of from July to September. Aerial survey results show over 1000 beluga whales aggregate there in the beginning of August (Glazov et al., 2012). South of the main aggregation, two significantly smaller and less dense aggregations were observed (up to 100-200 animals) spreading out along the navigation channels along the eastern and western shores of the Amur Estuary and entering the lower course of the Amur River. In the beginning of September, individual belugas were spotted south of the Amur Estuary near Pronge Cape.

During salmon runs, aggregations of beluga whales were seen regularly at the entrance of Baikal Bay on the northwestern coast of Sakhalin Island. Aerial survey results from 2009 and 2010 show 30 to 90 animals in this area (Fig. 4). 


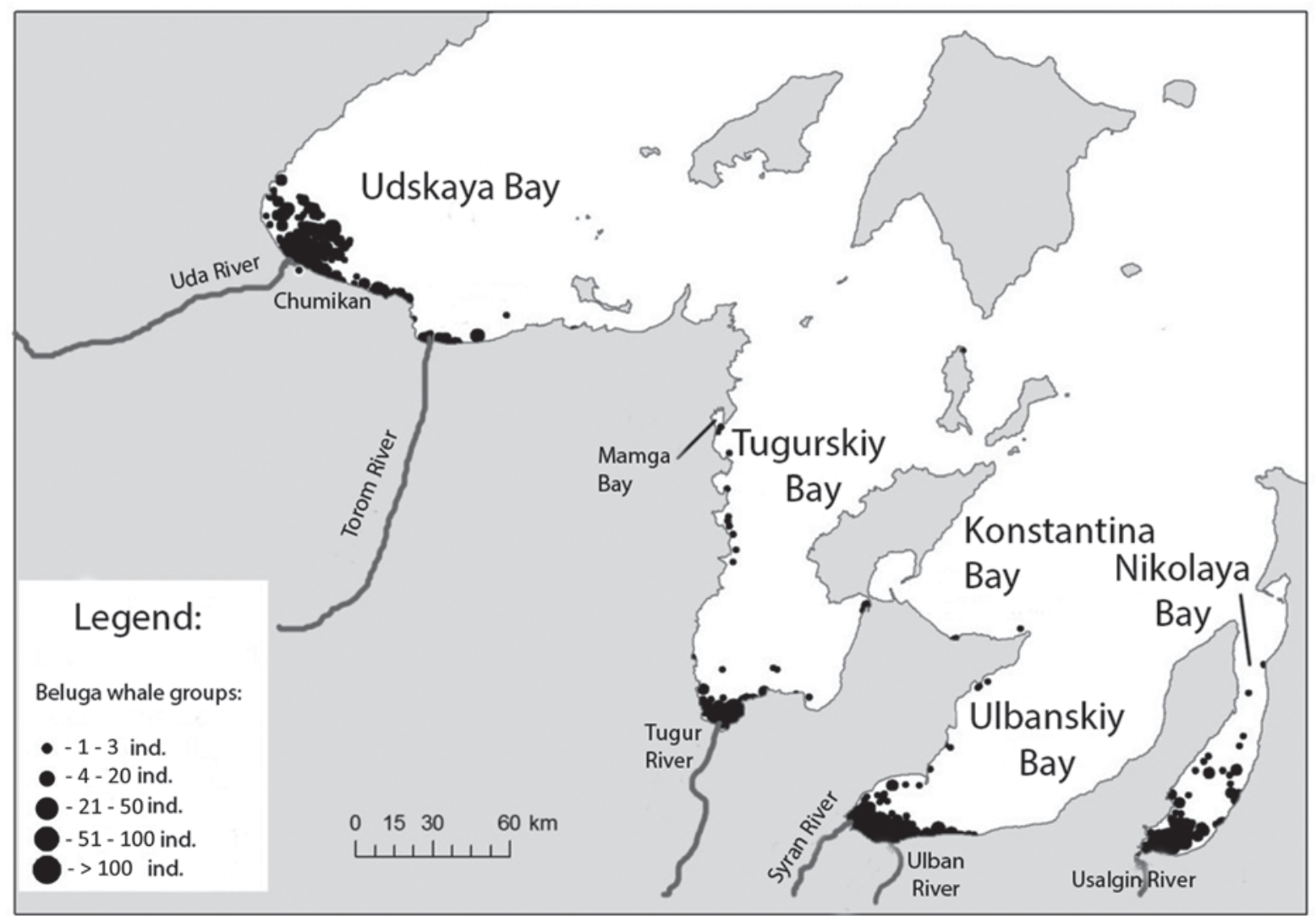

Fig. 5. Summer sightings of beluga whales in Shantar Region according to the results of the ship-based and aerial surveys in 2009-2013.

We observed no beluga whales in the northern quarter of Sakhalinskiy Bay, and according to the satellite tracking data, in summer beluga whales did not go to the deep-water areas of the bay. Fishermen mentioned that beluga whales leave the Sakhalin-Amur region when autumn chum salmon run ends in September or October, and this was also confirmed by the satellite tracking data. Some individual whales traveled from Sakhalinskiy Bay west to the adjacent bays in the Shantar region (Nikolaya and Ulbanskiy, Fig. 5) and spent autumn there before joining others, which moved directly northeast to offshore wintering areas (Shpak et al., 2010, Shpak et al., 2012; Shpak \& Glazov, 2013). Winter migration started upon beginning of ice-formation; before that tracked beluga whales kept in shallow waters of the bays and near the coastline.

\section{Shantar region}

Nikolaya Bay - According to evidence of interview respondents, beluga whales arrive in Nikolaya Bay in the second half of May or early June when capelin (Mallotus villosus), smelt and herring are spawning. In the second half of June, the whales return to the Usalgin River estuary when salmon runs start.

According to our data, from late June to mid-July, individual whales are seen in Nikolaya Bay (up to 10-
15 animals), and in the second half of July the numbers increase up to 50 whales as pink salmon and chum salmon runs start. Beluga whales were primarily in the southern part of the bay in the Usalgin River estuary (Fig. 5). They disperse in the area in small groups or individually. With the beginning of high tide they may go 3 or 4 kilometres $(\mathrm{km})$ up the river, but they return to the bay before the falling tide.

Aerial survey observations included 37 and 54 beluga whales in Nikolaya Bay in the first half of August 2009 and 2010, respectively; however, only 6 belugas were spotted there in the beginning of September 2009. In the second half of August 2012, only individual whales were spotted in the bay. As mentioned in the Sakhalin-Amur region section, satellite tracking data show that from late August to early September some beluga whales move from Sakhalinskiy Bay to Nikolaya Bay. Some tracked individuals remain there until the end of autumn when ice formation begins. Also, some beluga whales move further west to Ulbanskiy Bay. Two beluga whales, tagged a year earlier in Sakhalinskiy Bay, were photographed in Nikolaya Bay next summer. Thus, there is some exchange between the aggregations of beluga whales summering in these regions. It is not clear whether beluga whales migrate between the two bays within one season, or if they spend the entire summer within 
one bay before moving to another the following summer.

Ulbanskiy Bay - According to evidence of respondents, beluga whales appear in small number in U1banskiy Bay in May, immediately after breakup of the fast ice even though the entrance of the bay remains covered with dense ice up to the middle of July. Beluga whales move south into the bay in large numbers in the $3^{\text {rd }}-4^{\text {th }}$ week of July and disperse within $10 \mathrm{~km}$ of the Ulban and Syran River mouths. Groups of 10-30 belugas are also seen along the western coastline of U1banskiy Bay and the southern coast of Konstantina Bay.

During the aerial surveys in August, an estimated 1200 beluga whales occupied the estuary where the Ulban and Syran Rivers enter Ulbanskiy Bay (Fig. 5). Whales were in several large aggregations of 100-300 belugas.

Beluga whale behaviours were noted during ship and shore based observations collected in Ulbanskiy Bay. These behaviours included traveling, feeding, resting, and socializing. Feeding and movements between different feeding areas within the estuary, or in connection with high and low tides were observed most often. A specific behaviour associated with avoiding predators - killer whales (Orcinus orca (Linnaeus, 1758)), was observed twice - the beluga whales moved rapidly in surf keeping as close to shore as possible.

The age structure of the beluga aggregations in Ulbanskiy Bay (based on skin colour: Kleinenberg et al., 1964; Matyshev \& Ogniotov, 2006) is similar to large summer aggregations from other bays in the Shantar region and along the Kamchatka Peninsula. White belugas (adults) make up $60-80 \%$ of the total number of belugas in the aggregation (Fig. 5). The dark-grey belugas (yearlings and young-of-the-year) make up about $10 \%$, but the age-ratio in certain groups of the aggregation may be very different: there are groups formed almost entirely by females with juveniles.

Tugurskiy Bay - According to results of coastal observations, in the Tugur River estuary beluga whales are seen in small numbers, no more than 20 belugas, in June or the first half of July. By the last days of July or early August, their numbers begin to increase. Results of the aerial surveys in August 2010 show up to 750 beluga whales in this area (Fig. 5). Results from our ship-based surveys in early August 2013 were similar at the peak of the salmon run the river mouth was "blocked" by an aggregation of over 500 beluga whales lined in ranks. Whales were observed in the estuary primarily during high tide as the low tide exposes thousands of meters of mudflats.

The number of beluga whales reduces notably, to several dozen only, a few days after the end of the peak of the salmon run. We observed beluga whales in the area until the end of September (no observations were carried out later). According to evidence of our respondents, in the eastern 'pocket' of the bay near the Tugurskiy Isthmus, beluga whales are present in mid-October; and small groups of belugas (up to 20 whales) are frequently seen in Mamga Bay $(70 \mathrm{~km}$ north of the Tugur River estuary). During the aerial surveys in 2009 and 2010, individual belugas were seen along the entire west coast of Tugurskiy Bay. It is presumed that beluga whales prefer the western part of the bay because the eastern shore lacks spawning rivers (S. Kulbachniy, KhabTINRO, pers. comm.).

Similar to other bays and regions, the age structure of large aggregations in Tugurskiy Bay included all age classes during all years of observation (Fig. 6) while small groups of adult beluga whales were not uncommon.

Udskaya Bay - Respondents from the settlement of Chumikan (on the Uda River) noted that in spring, beluga whales enter the river estuaries as soon as the sea ice retreats. For example, in 2014 the sea ice cover broke unusually early, and beluga whales were seen near the settlement in late April for the first time. We hypothesize that beluga whales enter the bay along the west coast because these coastal areas are the first to become ice-free within Udskaya Bay. In other years, beluga whales first arrive in early or mid-June. Beluga whales are always present in Udskaya Bay at the start of the smelt run. Based on our observations and interviews, in the middle or by the end of July, the number of beluga whales peaks and remains at this level, with some fluctuations, until early or mid-September. In autumn, the number of belugas near Chumikan gradually falls. Based on coastal observations, up to 100-120 beluga whales remain until ice slush starts to form, usually in the middle of November.

During the first third of August 2009, aerial surveys found beluga whales concentrated in two areas: 850 whales in the estuary of the Uda River near Chumikan and 100 whales in the Torom River estuary (Fig. 6). During this same period in 2010, all beluga whales (about 1200 animals) were observed in the Uda River estuary.

The surveyed aggregation of beluga whales appears to be a large reproductive herd (Fig. 6). In groups concentrating near the coast, the number of juveniles reaches 30-40\%. Many newborns are observed in the second half of July. Re-sightings of photographed individuals with scars from biopsy tips confirm the recurring presence of the same individuals in these coastal groups. Similar to the adjacent bays in the Shantar region, beluga whale movements within the estuaries of Udskaya Bay are effected by tides. Extreme low tides expose mudflats and displace whales several kilometres from the river mouths.

Thus, according to evidence of respondents, small numbers of beluga whales appear immediately after break up of shorefast ice in the Shantar region. Evidently, they are able to traverse ice fields that may block the entrances to some bays (e.g., Nikolaya Bay, Ulbanskiy Bay). The early arrival of beluga whales coincides with the beginning of herring, smelt and capelin runs.

By the middle of summer beluga whales gather in and near the estuaries of large rivers. The largest aggregations of beluga whales (over 1000 animals) were 


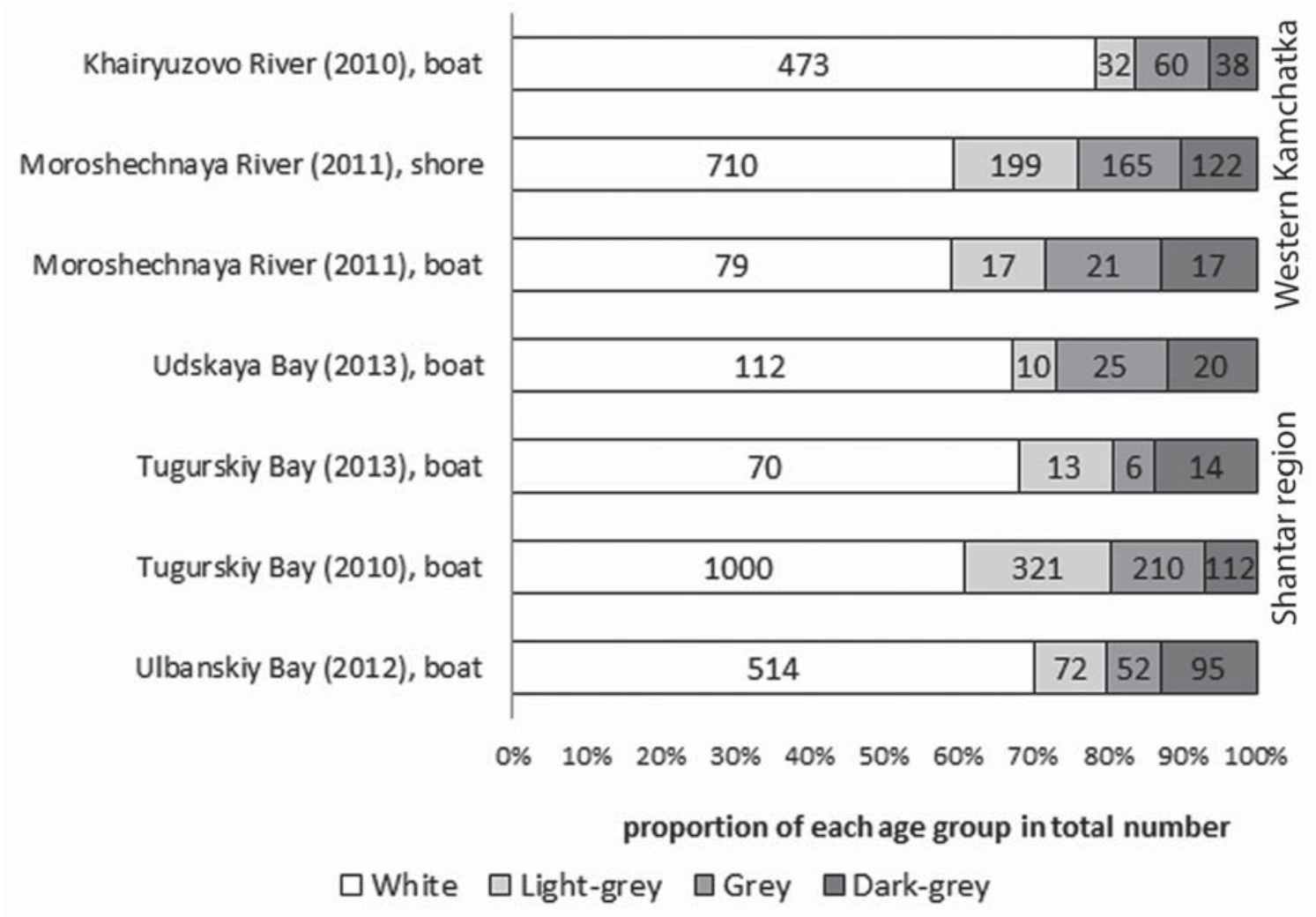

Fig. 6. The age distributions of several summer aggregations of beluga whales in the Sea of Okhotsk determined during the ship and shore based observations in 2010-2013.The areas and methods of observation are shown on the vertical axis.

observed in Ulbanskiy Bay and Udskaya Bay, while the smallest were in Nikolaya Bay.

Movement patterns within the estuaries are related to tidal sea level changes, which vary in this region in summer from $3.5 \mathrm{~m}$ to $7.8 \mathrm{~m}$.

The social structure of the aggregations was variable and depends, most likely, on the pattern of food distribution. Large groups were comprised of hundreds of whales that included subgroups of whales of 3-30 animals in close proximity to one another. Isolated small groups consisting of several belugas were also seen along the coastlines outside of the river estuaries.

\section{Northwestern region}

Seemingly, at present there are no permanent summer aggregations of beluga whales anywhere along the northwestern coast of the Sea of Okhotsk between Udskaya Bay and Shelikhov Bay (Fig. 7). During the 2009 aerial survey, only individual whales or small groups travelling along the coast have been observed. Beluga whales were seen in two locations: in the estuary of the Inya River on the administrative border between Khabarovskiy Territory and Magadanskaya Region (one adult with a juvenile) and in the western part of Tauyskaya Bay (two groups comprised of 9 adults with 2 juveniles and one adult with a juvenile).
In late May - early June 2008, when ice was still present near the coast, up to 1500 beluga whales entered Tauyskaya Bay and dispersed over the entire area, later leaving and heading east. Almost no feeding behaviour was observed during this time. The same year in late June, a group of 100-150 beluga whales appeared to be feeding on the bottom, probably on flatfish (Pleuronectidae), near Ola settlement, about 6-8 km from the river estuary (A.I. Grachev, Magadan NIRO, pers. comm.).

According to evidence of respondents (from Tukchi, Ayan and Okhotsk), beluga whales approach the northwestern coast in the spring following the breakup of fast ice, as spawning herring and smelt return. For example, 12 belugas were seen in Ayan Harbor on April 30, 2014.

On May 26-27, 2011, an aerial ichthyologic survey team observed ca. 270-300 belugas in groups of 10-30 animals in the herring spawning areas near Okhotsk town (A.I. Grachev, Magadan NIRO, pers. comm.).

\section{Discussion}

According to our data, beluga whales are not uniformly distributed along the entire coast of the Sea of Okhotsk during summer, but aggregate primarily in river estuaries and associated bays located in several 


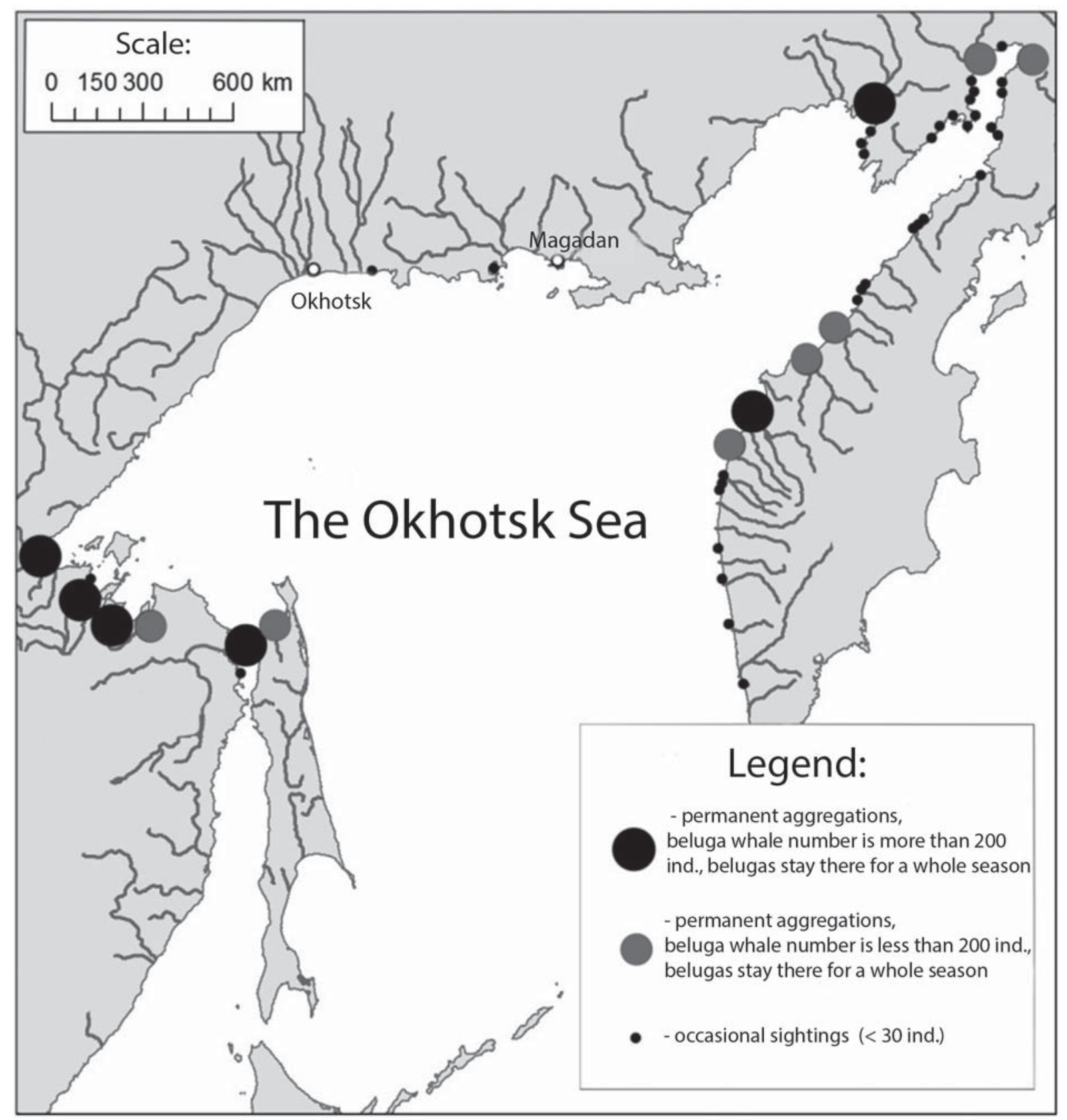

Fig. 7. The summer distribution of beluga whales in the Sea of Okhotsk.

regions. These regions include Sakhalinskiy Bay (and the estuary of the Amur River), continental bays of the Shantar region, some areas of Shelikhov Bay, and the northwestern coast of the Kamchatka Peninsula. Only rare occasional sightings of beluga whales occurred along the northwestern coast of the Sea of Okhotsk between the Shantar and Shelikov regions, in Tatarskiy Strait south of De Kastri settlement, near the eastern coast of Sakhalinskiy Island, and along the coast of the Kamchatka Peninsula south of the Moroshechnaya River. Similar to studies conducted in the $20^{\text {th }}$ century, we have not seen beluga whales in summer near the east coast of Kamchatka, the coast of East Sakhalin and in the northern part of the Sea of Japan. Although, beluga whales have been observed near the continental coast of Primorye region, the coasts of Hokkaido Island, and even the coast of Honshu Island (Sato \& Ichimura, 2011; Melnikov \& Seredkin, 2014), most sightings were of lone whales, "outliers" encountered between seasons in the period of active migrations.

Numbers of beluga whales found within each region have changed since the time of commercial whaling and scientific studies conducted during the $20^{\text {th }}$ century. When comparing the Shantar region to the SakhalinAmur region, we found that in early-middle 1980s the numbers in these regions were in a ratio of $1: 4$, by the end 
of the $1980 \mathrm{~s}$ and in the $1990 \mathrm{~s}$ this ratio changed as 1:2; however, by 2011 this ratio was 2:1 (Vladimirov, 1985, 1994, 1995; Berzin et al., 1988, 1990; Glazov et al., 2012). According to V.L. Vladimirov (1994, 1995), the ratio change in late $20^{\text {th }}$ century was a result of a decline in number of beluga whales in the Sakhalin-Amur region.

Within the Shantar region, present day estimates in each bay also differ greatly from beluga counts obtained 30-50 years ago. For example, more beluga whales were present in Tugurskiy Bay than in U1banskiy Bay (Berzin et al., 1988), while current estimates show almost three times as many whales in U1banskiy compared to Tugurskiy Bay. Although visual observations support the hypothesis of seasonal residency, the movements of Shantar belugas between the bays can not be excluded, given that satellite-tagged and photo-identified whales from the Sakhalin-Amur summer aggregation are known to travel to the eastern Shantar bays. Genetic analysis (Yazykova et al., 2012; Meshchersky et al., 2013) indicates that there are statistically significant differences in maternal lines in separate bays, except Nikolaya and Sakhalinskiy bays. As summer aggregations of beluga whales demonstrate pronounced philopatry fixed at the genetic level, it is unlikely that these aggregations travel from bay to bay and mix in numbers. We suppose there may be certain exchange between Sakhalinskiy and Nikolaya bays in summer months; but for most aggregations, highly residential behavior is characteristic during the months of chum and pink salmon runs, when most genetic sampling took place. In autumn, belugas become more mobile. We know that individual whales start moving from bay to bay, and that the number of belugas in places of summer concentration gradually decreases. The autumn movements of entire aggregations remain unknown, and it is possible that large summer aggregations disperse breaking into smaller groups, some of which remain on summer grounds until the winter migration starts.

According to the papers of the late $20^{\text {th }}$ century (Berzin et al., 1985; Berzin, 1995), most beluga whales observed in the northeastern Sea of Okhotsk were in the Shelikov region, concentrated in Penzhinskaya and Gizhiginskaya bays, with only small groups and individual belugas seen along the western coast of Kamchatka. Our studies show the numbers of beluga whales near the western coast of Kamchatka and in the Shelikhov region are approximately the same (Glazov et al., 2012). Tagged whales from the Kamchatka coast were observed traveling to the Shelikov region after the summer season suggesting there may be migratory movements between these two regions. Genetic analyses of samples collected along the west coast of Kamchatka (Meshchersky et al., 2012, 2013) compared to whales from the Sakhalin-Amur and Shantar regions suggest these populations are distinct one from another. Along the northwestern and northern coast of the Sea of Okhotsk, summer aggregations are no longer present. Prior to the 1930s, several hundred beluga whales were regularly seen in Tauyskaya Bay (Govorkov, 1930, 1931). Commercial whaling of belugas began in this bay in 1929, with 388 belugas caught in 1929, and 147 in 1930 (Govorkov, 1930, 1931). It is unknown whether the aggregation in Tauyskaya Bay was extirpated, or belugas left this area. Haplotypes characteristic of the northeastern population are present in belugas aggregating in Udskaya Bay (Meshchersky et al., 2012, 2013). It is possible that Tauyskaya aggregation abandoned its summer ground and mixed with belugas from Udskaya Bay. Intensive commercial harvest in Sakhalin-Amur region, Tugurskiy and Udskaya bays and Gizhiginskaya Bay, which lasted longer than whaling in Tauyskaya Bay, did not result in the disappearance of the respective summer aggregations of beluga whales suggesting that these areas play key role as feeding or/ and breeding habitats similar to distribution pattern of Cook Inlet belugas described below.

The summer distribution and behaviour of beluga whales in the Sea of Okhotsk is typical for the subarctic and temperate zone seas. For example, belugas form similar summer aggregations in the Anadyr Estuary of the Bering Sea. Anadyr belugas also approach the coast after the ice breaks up in late spring or early summer, feed intensively on anadromous species of fish, and leave the bay when in October ice starts to form (Litovka et al., 2002).

The same pattern is also observed in the eastern part of the Bering Sea - in Norton Sound, where beluga whales aggregate in the estuary of the Yukon River from May to November, also feeding on salmon (Lowry et al., 1986). In Bristol Bay, Alaska, belugas gather in the Kvichak and Nushagak rivers from April to August following anadromous fish runs (Lowry et al., 2008). A small isolated population of beluga whales in Cook Inlet, Alaska, currently remains in the inlet yearround and aggregates in river deltas during the summer months to feed on anadromous runs of eulachon (Thaleichthys pacificus) and salmon and find shelter from killer whales (Shelden et al., 2003, Goetz et al., 2007, 2012). Similar to the whales in some regions of the Sea of Okhotsk, these whales were intensively hunted but did not abandon the Susitna delta area (Rugh et al., 2010). Instead as their numbers declined overall, numbers in this particular area remained fairly stable suggesting this aggregation area provided habitat preferred over other areas, even though this is where most hunting occurred. In the subarctic and northern seas of the Atlantic, beluga whales are similarly distributed in summer in the Gulf of Saint Lawrence where they go up the estuary of the Saint Lawrence River after the ice retreats (Kingsley, 1999; COSEWIC, 2004), as well as in the western part of Hudson Bay, where beluga whales gather in the estuaries of the Churchill, Nelson and Seal rivers to feed on salmon (Sergeant, 1973).

The distribution patterns and behaviour of beluga whales in the Arctic seas are notably different. Estuarine and coastal waters play much less role in belugas summer distribution in the Arctic seas. When beluga 
whales enter a bay, river estuary, or near shore waters, they go in small numbers or for a short period of time, without forming stable aggregations gravitating to certain locations. These whales also typically undertake much longer migrations covering thousands of kilometres from their summering grounds to their wintering areas. For example, this is the case in such locations as Obskaya Bay, Yeniseiskiy Bay, the Lena River estuary, Kasegalyuk Bay, Kotzebue Sound, the Mackenzie River estuary, and Somerset Island (Norton \& Harwood, 1986; Frost et al., 1993; Smith \& Martin, 1994; Richard et al, 2001a, b; Solovyev et al., 2011; Udovik et al., 2012). These regions do not host large, anadromous fish runs and remain ice-covered for longer periods than the subarctic and boreal seas. In a warming arctic, there is already evidence of salmon numbers increasing farther north than ever documented in the past (Dunmall et al., 2013). It will be interesting to see how these changes may affect the behaviour of these northern populations of belugas as sea ice disappears and anadromous fish become a part of their ration.

ACKNOWLEDGEMENTS. The study was conducted as cooperative research of the Program 'The White Whale' of the Permanent Expedition of the Russian Academy of Sciences (RAS) (A.N. Severtsov Institute of Ecology and Evolution, RAS) and the Project 'Current status of the Sakhalin-Amur beluga aggregation (Sea of Okhotsk, Russia): sustainability assessment' ("Dolphin and I" Ltd, Marine Mammal Council) with the financial support of the Russian Geographical Society, Ocean Park Corporation (Hong Kong); Georgia Aquarium Inc., Seaworld Parks \& Entertainment, Mystic Aquarium and Institute for Exploration (USA); Kamogawa Sea World (Japan).

The authors would like to thank all the participants of the field studies on the distribution of beluga whales in the Sea of Okhotsk - V.I. Chernook, E.A. Nazarenko, A.N. Vasiliev, A.I. Grachev, A.Yu. Paramonov, D.I. Ivanov, D.A. Udovik, T.C. Shulezhko, K.K. Tarasyan, F.V. Kazansky, A.N. Kanzeparova, S.E. Kulbachniy, E. Molchanova, R. Michaud, M. Moisan. The authors would like to thank Kim Shelden and Olga Filatova for comments and suggestions, which have greatly improved the manuscript, and Dr. Shelden's extraordinary help on English correction.

\section{References}

Arseniev V.A. 1939. [Distribution and migrations of belugas in the Far East] // Izvestiya TINRO. Vol.15 (monograph). 109 p. [in Russian]

Berzin A.A. \& Yakovlev A.V. 1978. [The numbers and population structure of the main whale species used commercially worldwide] // Zoologicheskii Zhurnal. Vol.57. No.12. P.1771-1785 [in Russian].

Berzin A.A., Vladimirov V.L. \& Doroshenko N.V. 1988 [The results of the aerial surveys for studying the distribution and numbers of whales in the coastal waters of the Sea of Okhotsk in 1986-1987] // [Studies of marine mammals of the northern part of the Pacific in 1986/87]. Moscow: VNIRO. P.28-24 [in Russian].

Berzin A.A. Vladimirov V.L. \& Doroshenko N.V. 1990 [The results of the aerial surveys for studying the distribution and numbers of polar, grey and beluga whales in the Sea of Okhotsk in 1985-1989] // Izvestiya TINRO. Vol.112. P.51-60 [in Russian].

Berzin A.A. \& Vladimirov V.L. 1989. [The current distribution and numbers of whales in the Sea of Okhotsk] // Biologiya morya. No.2. P.19-23 [in Russian].

Chereshnev I.A., Volobuev V.V., Khovanskiy I.E. \& Shestakov A.V. 2001. [Coastal fish of the northern part of the Sea of Okhotsk]. Vladivostok: Dalnauka. 196 p. [in Russian]

COSEWIC assessment and update status report on the beluga whale Delphinapterus leucas in Canada. 2004. Committee on the Status of Endangered Wildlife in Canada. Ottawa. IX $+70 \mathrm{p}$.

Dunmall K.M., Reist J.D., Carmack E.C., Babaluk J.A., Heide-Jørgensen M.P. \& Docker M.F. 2013. Pacific Salmon in the Arctic: Harbingers of Change // Mueter F.J., Dickson D.M.S., Huntington H.P., Irvine J.R., Logerwell E.A., MacLean S.A., Quakenbush L.T. \& Rosa C. (eds.), Responses of Arctic Marine Ecosystems to Climate Change. Alaska Sea Grant, University of Alaska Fairbanks. P.141-160.

Fedoseev G.A. 1986. [Seasonal changes in the distribution and environmental differentiation of beluga whales in the northern Pacific and eastern Arctic] // [Studying, protection and sustainable use of marine mammals: Thesis reports of the $9^{\text {th }}$ All-Union Conference on studying, protection and sustainable use of marine mammals (Arkhangelsk, Sept 9-11, 1986)]. Arkhangelsk: Rotaprint Oblstat. P.406-408 [in Russian].

Frost K.J., Lowry L.F. \& Carroll G. 1993. Beluga whale and spotted seal use of a coastal lagoon system in the northeastern Chukchi Sea // Arctic. No.46. P.8-16.

Glazov D.M., Chernook V.I., Zharikov K.A., Nazarenko E.A., Mukhametov L.M. \& Boltunov A.N. 2008. Aerial surveys of white whales (Delphinapterus leucas) in July in the White Sea (2005-2007), distribution and abundance // Marine mammals of the Holarctic. Collection of studies presented at the $5^{\text {th }}$ International Conference. Odessa: MMC. P.194-198.

Glazov D.M. Chernook V.I., Shpak O.V., Solovyev B.A., Nazarenko E.A., Vasilev A.N., Chelintsev N.G., Kuznetsova D.M., Mukhametov L.M. \& Rozhnov V.V. 2012. The results of beluga whale (Delphinapterus leucas) aerial surveys in the Okhotsk Sea in 2009 and 2010 // Marine mammals of the Holarctic: Collection of studies presented at the $7^{\text {th }}$ International Conference. Suzdal: MMC. P.167-172.

Goetz K.T., Rugh D.J., Read A.J. \& Hobbs R.C. 2007. Habitat use in a marine ecosystem: Beluga whales Delphinapterus leucas in Cook Inlet, Alaska // Marine Ecology Progress Series. Vol.330. P.247-256.

Goetz K.T., Montgomery R.A., Ver Hoef J.M., Hobbs R.C. \& Johnson D.S. 2012. Identifying essential summer habitat of the endangered beluga whale Delphinapterus leucas in Cook Inlet, Alaska // Endangered Species Research. Vol.16. P.135-147. 
Govorkov I.V. 1930. [Commercial hunting of beluga whales in Tauyi in the 1929 season] // Rybnoe Khozyaystvo Dalnego Vostoka. No.2. P.17-22 [in Russian].

Govorkov I.V. 1931. [Commercial hunting of beluga whales in Tauyi in the 1930 season] // Rybnoe khozyaystvo Dalnego Vostoka. No.1-2. P.60-63 [in Russian].

Hobbs R.C., Laidre K.L., Vos D.J., Mahoney B.A. \& Eagleton M. 2005. Movements and Area Use of Belugas, Delphinapterus leucas, in a Subarctic Alaskan Estuary // Arctic. Vol.58. No.4. P.331-340.

Kingsley M.C.S. 1999. Population indices and estimates for the belugas of the St. Lawrence estuary. Canadian Technical Report Fisheries \& Aquatic Science 2266. Regional Science Branch Department of Fisheries and Oceans Maurice Lamontagne Institute. Mont-Joli. VII + 27 p.

Kleinenberg S.E., Yablokov A.V., Belkovich V.M. \& Tarasevich M.N. 1964. [Beluga. Monographic study of a species]. Moscow: Nauka. 455 p. [in Russian]

Laidre K.K., Stirling I., Lowry L.F., Wiig O., Heide-Jorgensen M.P. \& Ferguson S.H. 2008. Quantifying the sensitivity of arctic marine mammals to climate-induced habitat change // Ecological Applications. Vol.18. Supplement: Arctic Marine Mammals. P.S97-S125.

Litovka D.I., Hobbs R.S., Laidre C.L., O'Corry-Crow G.M., Orr J.R., Richard P.R., Sewdam R.S. \& Kochnev A.A. 2002. [Telemetric studies of beluga whales (Delphinapterus leucas) in the Anadyr Gulf (Chukotka)] // Belkovich V.M. (ed.). [Marine mammals of Holarctic]. Moscow: SMM. P.161-163 [in Russian].

Lowry L.F., Frost K.J. \& Seaman G.A. 1986. Investigation of belukha whales in coastal waters of western and Northern Alaska // NOAA, OCSEAP. Vol.56. P.359-391.

Lowry L.F., Frost K.J., Zerbini A., De Master D. \& Reeves R.R. 2008. Trend in aerial counts of beluga or white whales (Delphinapterus leucas) in Bristol Bay, Alaska, 1993-2005 // Journal of Cetacean Research and Management. Vol.10. No.3. P.201-207.

Melnikov V.V. \& Seryodkin I.V. 2014. [Sightings of beluga whales (Delphinapterus leucas) in the Sea of Japan] // [Reports of International Applied Science: Habitats, migrations and other movements of animals]. Vladivostok. P.196-198 [in Russian].

Melnikov V.V. 2001. [Beluga whales of the Sea of Okhotsk] // [Research work on marine mammals in the North Pacific in 1991-2000]. Moscow: VNIRO. P.51-58 [in Russian].

Meschersky I.G., Shpak O.V., Glazov D.M., Litovka D.I., Borisova E.A., Yazykova M.G.\& Rozhnov V.V. 2012. Beluga whale (Delphinapterus leucas) in Far Eastern seas: mtDNA lines assortment and distribution // Marine mammals of the Holarctic: Collection of studies presented at the $7^{\text {th }}$ International Conference. Suzdal: MMC. P.90-95.

Meschersky I.G., Shpak O.V., Litovka D.I., Glazov D.M., Borisova E.A. \& Rozhnov V.V. 2013. A genetic analysis of the beluga whale Delphinapterus leucas (Cetacea: Monodontidae) from summer aggregations in the Russian Far East // Russian Journal of Marine Biology. Vol.39. No.2. P.125-135.

Norton P. \& Harwood L.A. 1986. Distribution, abundance and behavior of white whale in Mackenzie estuary.
Environmental Studies Revolving Funds. Rep.36. Ottawa. $73 \mathrm{p}$.

R Development Core Team 2008. R: A language and environment for statistical computing. R Foundation for Statistical Computing, Vienna, Austria.

Richard P.R., Heide-Jorgensen M.P., Orr J.R., Dietz R. \& Smith T.G. 2001a. Summer and autumn movements and habitat use by belugas in the Canadian High Arctic and adjacent areas // Arctic. Vol.54. No.3. P.207-222.

Richard P.R., Martin A.R. \& Orr J.R. 2001b. Summer and Autumn Movements of Belugas of the Bastern Beaufort Sea Stock // Arctic. Vol.54. No.3. P.223-236.

Rugh D.J., Shelden K.E.W. \& Hobbs R.C. 2010. Range contraction in a beluga whale population // Endangered Species Research. Vol.12. P.69-75.

Sato H. \& Ichimura M. 2011. The Sighting Record of Beluga (White Whale) Delphinapterus leucas in Shiretoko-Nemuro Strait Water, Eastern Hokkaido, Japan // Bulletin of the Shiretoko Museum. No.32. P.45-52.

Sergeant D.E. 1973. Biology of white whales (Delphinapterus leucas) in western Hudson Bay // Journal of the Fisheries Research Board of Canada. Vol.30. P.10651090.

Sergeant D.E. \& Brodie P.F. 1969. Body size in white whales, Delphinapterus leucas // Journal of the fisheries research board of Canada. Vol.26. No.10. P.2561-2580.

Shelden K.E.W., Rugh D.J., Mahoney B.A. \& Dahlheim M.E. 2003. Killer whale predation on belugas in Cook Inlet, Alaska: Implications for a depleted population // Marine Mammal Science. Vol.19. No.3. P.529-544.

Shpak O.V. \& Glazov D.M. 2013. [Sustainable commercial use of beluga whales (Delphinapterus leucas) in the northern Sea of Okhotsk and western Kamchatka zones] // Rybnoe Khozyaistvo. Vol.6. P.54-61 [in Russian].

Shpak O.V., Glazov D.M., Kuznetsova D.M., Mukhametov L.M. \& Rozhnov V.V. 2012. Migratory activity of the Okhotsk Sea belugas Delphinapterus leucas in winterspring period // Marine mammals of the Holarctic: Collection of studies presented at the $7^{\text {th }}$ International Conference. Suzdal: MMC. P.390-395.

Shpak O.V., Andrews R.D., Glazov D.M., Litovka D.I., Hobbs R.C. \& Mukhametov L.M. 2010. Seasonal migrations of Sea of Okhotsk beluga whales (Delphinapterus leucas) of the Sakhalin-Amur summer aggregation // Russian Journal of Marine Biology. Vol.36. No.1. P.56-62.

Shulezhko T.S., Solovyev B.A., Gorin S.L., Tarasyan K.K., Kazansky F.V., Glazov D.M. \& Rozhnov V.V. 2013. [Preliminary results of the studies of the summer aggregation of beluga whales (Delphinapterus leucas) in the Estuaries of the Khairyuzova, Belogolovaya and Moroshechnaya Rivers (western Kamchatka)] // [The studies of aquatic biological resources of Kamchatka and the north-western part of the Pacific]. No.28. P.71-83 [in Russian].

Smith T.G. \& Martin A.R. 1994. Distribution and movements of belugas, Delphinapterus leucas, in the Canadian High Arctic // Canadian Journal of Fisheries and Aquatic Sciences. No.51. P.1653-1663.

Solovyev B.A., Platonov N.G., Glazov D.M., Shpak O.V. \& Rozhnov V.V. 2011. Distribution of beluga whales 
(Delphinapterus leucas) in the Russian Arctic seas according to the results of expedition aboard RV Mikhail Somov, September-November 2010 // Biology Bulletin. Vol.39. No.7. P.1398-1402.

Tarasyan K.K., Shulezhko T.S., Udovik D.A., Russkova O.V., Glazov D.M. \& Rozhnov V.V. 2013. [Using the photo ID method for studying summer aggregations of beluga whales (Delphinapterus leucas) in the estuaries of the rivers of Northern Kamchatka] // [The studies of aquatic biological resources of Kamchatka and the northwestern part of the Pacific]. No.28. P.41-49 [in Russian].

Udovik D.A., Solovyev B.A., Kuznetsova D.M., Shpak O.V., Platonov N.G., Glazov D.M. \& Rozhnov V.V. 2012. Marine mammal observations in the Russian Arctic seas: results of Mikhail Somov research vessel expeditions 2010 and 2011 // Marine mammals of the Holarctic: Collection of studies presented at the $7^{\text {th }}$ International Conference. Suzdal: MMC. P.306-311.

Vladimirov V.L. 1994. [The current distribution and numbers of whales in the far eastern seas] // Biologiya Morya.
Vol.20. No.1. P.3-13 [in Russian].

Vladimirov V.L. 1995. [The distribution and numbers of beluga whales in the Sea of Okhotsk] // [Thesis reports of International Conference on Study and Preservation of Marine Mammals], Golitsino. P.30-31 [in Russian].

Vladimirov V.L. 1985. [The distribution and numbers of beluga whales in the Sea of Okhotsk] // [Study and sustainable use of the biological resources of the far eastern and northern seas of the USSR and the prospects for developing technical capabilities for using commercially the biological resources of the open ocean: Thesis reports of All-Union Conference (Vladivostok, Apr. 1517, 1985)]. Vladivostok: Dalryba. P.85-86 [in Russian]. Yazykova M.G. Meschersky I.G., Shpak O.V., Glazov D.M., Litovka D.I., Borisova E.A.\& Rozhnov V.V. 2010. Molecular genetic analysis of Sakhalin-Amur and Shantar beluga (Delphinapterus leucas) summer aggregation in the Sea of Okhotsk // Marine mammals of the Holarctic: Collection of studies presented at the $7^{\text {th }}$ International Conference. Suzdal: MMC. P.408-413. 